\title{
The Human Element in Shipping Casualties as a Process of Risk Homeostasis of the Shipping Business
}

\author{
Juan Vinagre-Ríos ${ }^{1}$ and Santiago Iglesias-Baniela ${ }^{2}$ \\ ${ }^{1}$ (Vessel Surveyor) \\ ${ }^{2}$ (Navigation and Earth Sciences Department, A Coruña University, Spain) \\ (E-mail: sbaniela@udc.es)
}

\begin{abstract}
Evidence for the existence of risk compensation behaviour in the operation of vessels is shown in the paper The Risk Homeostasis Theory (Baniela and Ríos, 2010). In that analysis, it is concluded that the people engaged in the commercial affairs of ships tend to exchange the level of safety standard of vessels for a more profitable and riskier activity, which makes the rate of shipping accidents fluctuate within certain limits. Since the different levels of power and motivation of those involved in the risk-taking process were not considered in that research, it is the aim of this paper to analyse, on the one hand, how the pressure of the shipping market influences the risk behaviour of shipping business decision-makers and to show, on the other hand, how this influence makes them alter their target level of risk and introduce risks related to low operating cost strategies on vessels. This behavioural adaptation to the shipping market demand has led the human element to be regarded as a factor of risk in the activity of commercial vessels. In this context, the increasing incidence of human errors has arisen as a consequence of practices and manning policies established by the managers of shipping companies.
\end{abstract}
KEYWORDS
1. Shipping market.
2. Risk homeostasis.
3. Human error.
4. Shipping casualties.

Submitted: 3 October 2012. Accepted: 27 October 2012. First published online: 12 March 2013.

1. INTRODUCTION. Despite the great improvements in the safety of commercial vessels, the frequency of shipping casualties has not decreased (The Motorship, 2007). This fact is reflected in the statistics and accepted by stakeholders of the maritime industry (The Motorship, 2011b). In Figure 1, it is shown that the rate of serious accidents involving vessels ( 500 grt, or above) which comply with international safety standards has not followed a downward trend for the last 18 years, as might have been expected if these standards had had any effect whatsoever. On the contrary, a general exploration of this time sequence shows, on one hand, a cyclic behaviour and, on the other, a tendency to maintain a certain value. 


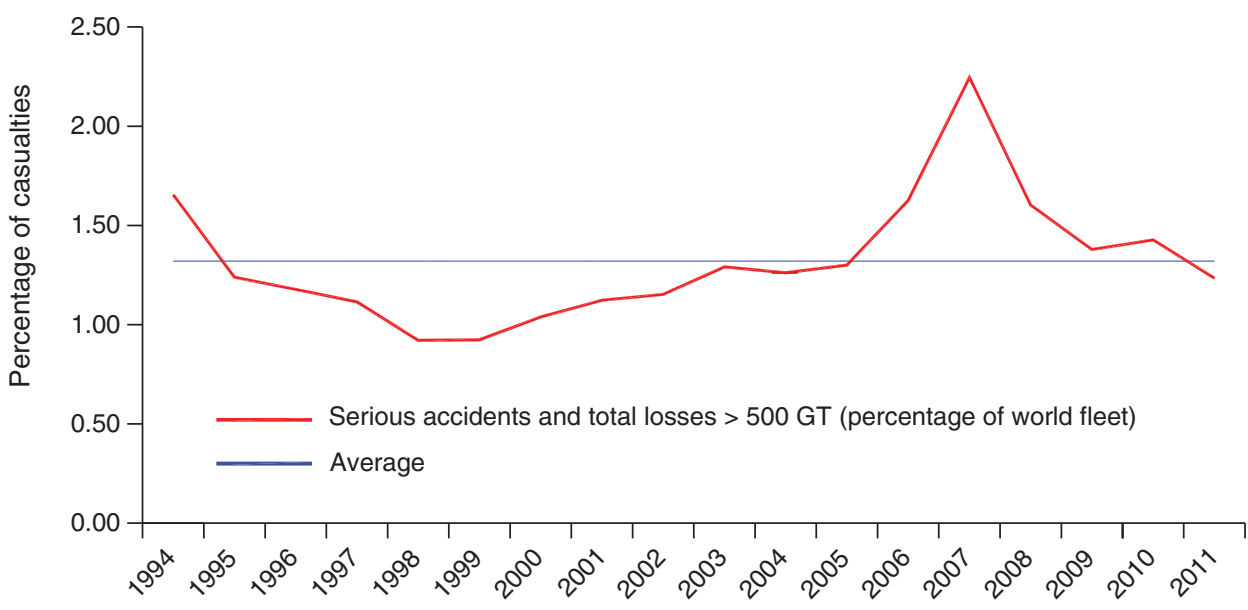

Figure 1. Percentage of serious and total losses of vessels of more than 500 grt. Source: International Union of Marine Insurance (IUMI) (http://www.iumi.com).

A rough analysis of the cyclic fluctuations reflects that the percentage of the world fleet involved in serious accidents moves up and down. A trough in the rate of accidents in the year 1998 corresponds with the setback of the world economy triggered by the Asian crisis in the middle of 1997 (UNCTAD, 1999, p. 1); a peak of mishaps in the year 2007 coincides with the robust world economic growth mainly driven by China and India during this and previous years (UNCTAD, 2008, p. 1); and a fall in the rate of casualties after 2008 takes place at the same time as the great economic contraction that followed the global financial crisis of 2008 and later years (UNCTAD, 2010, p. 2). These concomitant alterations suggest a causal link between economic circumstances and the occurrence of shipping casualties.

Apart from these short-term oscillations, it can be observed in Figure 1 that the cyclic alterations in the rate of casualties fluctuate around an average of $1.32 \%$ of the vessels of the world fleet. This long-term trend shows that the exchange of safety advances for greater productivity has prevented a decrease in the amount of risk whom those engaged in the operation of commercial vessels are willing to take (Baniela and Ríos, 2010). This process is explained by the risk homeostasis theory (Wilde, 1998).

The reference to the economic circumstances as a distorting factor in the level of risk taken in shipping affairs leads us to consider that both components of the time sequence of the rate of accidents shown above, non-periodic fluctuations and longterm trend, should be expected to be influenced by the economy. The known fact that seaborne trade is an activity strongly affected by the economic situation (UNCTAD, 2011, p. 2) and inevitably associated with perils (Boisson, 1999, pp. 37-39), to the extent of making shipping entrepreneurs famous for taking risks (Stopford, 2009, p. 338), consistently supports this presumption.

In business circles, it is accepted that the risk profile will determine the company's earnings over the business cycle (Lam, 2003, p. 4). This principle leads us to accept that it is the massive incentive of potential benefits in the operation of ships that makes ship-owners assume great risks. Such a perspective points to shipping business decision-makers as the driving force behind the risk taking process on vessels, which 
seems reasonable, since they are the most interested in gaining profits from the operation of their ships.

Nevertheless, when the complexity of the industry is taken into account, controversy arises. There are many people involved in the activity of vessels, but it is the Master who is traditionally held responsible for the safety of his ship by maritime laws (Heitzmann, 2006, p. 90). Although this practice has made it commonplace for the initiation of criminal proceedings against Captains in the event of accidents (Lloyd's List, 2012d), facts also show that the risk behaviour of people on board is often conditioned by the ship-owners, who put at risk the quality and safety of vessels (Lloyd's List, 2012h). This interference by shipping companies has even reached the extent of often reducing safe manning in return for benefits, which has led stakeholders of the insurance industry to ask ship-owners to improve the safety of their vessels by making greater investment in ships' crews (The Motorship, 2005). To explain the risk homeostasis process that is taking place in the operation of vessels nowadays, both aspects, the leading role of shipowners in the risk taking activity and the tendency of shipping companies to exchange the level of safety of their vessels for a more profitable activity, will be addressed in this work.

The first objective of the present paper is to analyse whether the fluctuations in the level of profits of the shipping companies, depending on economic circumstances, keep pace with the alterations in the rate of mishaps observed in Figure 1. Psychological theory supports this synchrony since it considers that when facing a venture, for a particular level of costs, the higher the benefits the greater the amount of risk that people are willing to take (Wilde, 1994). In the maritime business, the level of benefits of each operation depends not only on the ability of ship-owners to make their vessels competitive, but also on the freight market (The Motorship, 2012a) whose volatility and substantial changes over short time spans are known (Talley, 2012, p. 108). This particularity makes the acceptability of risks in the operation of vessels be modified by the shipping market circumstances.

The second objective of this paper is to investigate how the market influences ship owners' risk behaviour and leads them to establish long-term strategies related to the profitability of their business. The most relevant of these policies are those related to manning cost reductions (BIMCO/ISF, 2010). It is reasonable to expect such risk behaviour because, for a particular level of benefits, reducing the operating costs of the vessels can increase the profitability of the shipping business.

\section{THE SHIPPING MARKET FLUCTUATIONS AND THE} OCCURRENCE OF ACCIDENTS. The sea is considered a very hostile environment, this is the reason why the activity of ships is associated to a great diversity of risks; actually, the simple mobility of vessels always implies an intrinsic amount of risk (Boisson, 1999, p. 31). The freedom to take part in the shipping business, where shippers and ship-owners negotiate to establish a price for transport, has made the freight market a highly volatile mechanism in which the rate fluctuates depending on the available ships and cargoes (Stopford, 2009, p. 160). These alterations influence the level of mobility of vessels (Lloyd's List, 2011f) and can even cause their commercial stagnation (Lloyd's List, 2012f); therefore, these fluctuations affect the inherent amount of risk assumed. 
Apart from the alterations in the degree of risk caused by changes in the freight rate, ups and downs in the level of benefits can turn particular risk options into desirable, or undesirable, alternatives for shipping companies. This happens whenever any risk choice is faced. However, it can be more easily seen when unacceptable risks associated with particular maritime ventures are made into tolerable options by a considerable increase in the freight price; when demand requires ships to operate in war zones or pirate areas for example (Lloyd's List, 2011e). In these cases, a sudden rise in freight rates arouses ship owners' interest in the enterprise. The certainty that huge benefits will be obtained is used to encourage crews to move the ships into those regions (Lloyd's List, 2008a), to pay higher premiums to the insurance industry (Lloyd's List, 2011g) and even to sign-on armed guards, if the risk venture makes it worthwhile (Lloyd's List, 2011b).

This leads us to consider that the freight market has a direct influence on the amount of risk assumed in maritime commercial activity. In this situation, and despite the ability of a particular shipping company to move their ships advantageously among the competitors, it is the shipping market which alters the level of benefits of ship-owners, and regulates the risk behaviour of those engaged in the operation of vessels. This means that the higher the freight rates are, the greater will be the tolerance of risk (Lloyd's List, 2011g). As a consequence, in an overall context, it can be assumed that, dependant upon the shipping market circumstances; the average target level of risk of the world commercial fleet will fluctuate.

Apart from these activities in the freight market, where ships for hire are traded, ship-owners also trade in other markets: buying and selling second-hand vessels, ordering new buildings or selling old ships for scrap. It is a known fact that the higher the benefits to ship-owners in the freight market, the greater their interest in building new ships (UNCTAD, 2011, p. 64). A higher demand for new ship-building indicates more activity of vessels and more profitable opportunities for ship-owners. Therefore, they will tend to impel their crews to face the risks associated with the activity, whereas a lower demand for new ship-building implies poor prospects in the commercial activity of ships. As a consequence, ship-owners will have less profitable risk alternatives in which to involve their vessels. This is the reason why the volume of orders of new building can be used as an accurate and stable indicator of the condition of the shipping market. This indicator will be employed to analyse the market influence on the occurrence of casualties.

According to the above theoretical approach, the condition of the shipping market (indicated by the volume of orders of new vessels) is expected to be closely correlated with the amount of risk tolerated by the world fleet (indicated by the frequency of accidents). The number of casualties and the level of new buildings from 1994 to 2011 have been obtained to investigate this matter. The data is shown in Figure 2.

The graph obtained for each group of data reflects a direct correlation between the two variables. Thus, the higher the ship-owners' demand for new ships, the greater the frequency of accidents and vice versa. To quantify the strength of this relationship, we obtain, in Table 1, the output of a linear model summary, in which the level of orders of new vessels is considered a predictor of the frequency of mishaps. $R$ is the correlation coefficient between the observed and predicted values of the frequency of accidents. $R$ values range from 0 to 1 and the large value of 0.865 indicates a strong relationship. $\mathrm{R}$ squared indicates the proportion of variation in the occurrence of casualties explained by the condition of the shipping market. In the present case, it can 
Table 1. Model Summary obtained for data at Figure 2 (output obtained with PASW Statistics 18).

\begin{tabular}{lcccc}
\hline \multicolumn{4}{c}{ Model Summary } \\
\hline Model & $\mathrm{R}$ & R Square & Adjusted R Square & Std. Error of the Estimate \\
\hline 1 & $\cdot 865^{\mathrm{a}}$ & .748 & .732 & $99 \cdot 00996$ \\
\hline
\end{tabular}

a. Predictors: (Constant), New-orders.

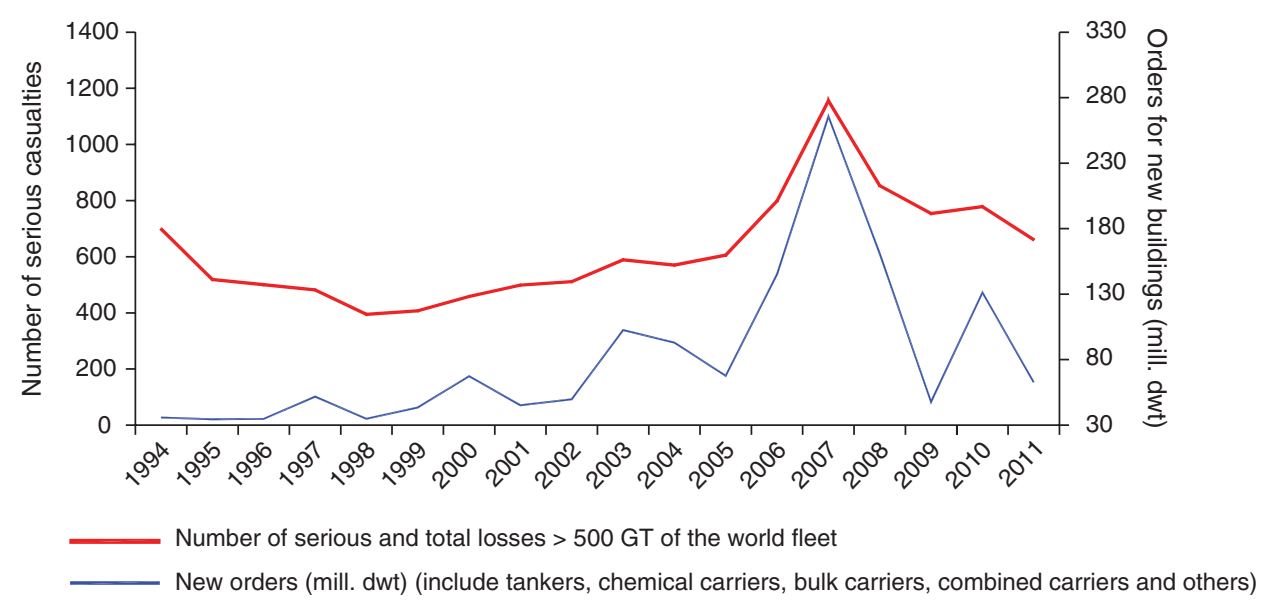

Figure 2. Demand for new buildings (mill. dwt) and number of serious casualties and total losses of vessels (over $500 \mathrm{grt}$ ) of the world fleet.

Sources: Platou (http://www.platou.com/dnn_site/Tables/Neworders.aspx) and IUMI (http://www. iumi.com).

be said that the level of profitability of the business, indicated by the volume of new orders, accounts for up to $75 \%$ of the occurrence of shipping casualties, which is an indicator of the amount of risk assumed by the shipping companies.

Many factors have an influence on both ship-owners' decisions to build new vessels and the occurrence of shipping accidents. Nevertheless, it must be accepted that, as a whole, these factors merge with the significant relationship shown in Table 1. This statistical result confirms that business activities, undertaken by ship-owners as a result of the observed trends of the shipping market, bear such a relationship to their risk behaviour that the degree of motivation to impel ships into assuming riskier ventures will depend upon the profits that ship-owners expect to receive. Research in other fields has already confirmed this association between economic fluctuations and the rate of accidents (Wilde and Simonet, 1996).

3. TRANSPORT COSTS AS A SOURCE OF RISK. Apart from the influence of the freight rate on the risk behaviour of ship-owners analysed above, other long-term aspects of the shipping market also affect their business activities. If we observe the evolution of the world seaborne trade from 1970 to 2010, as shown in Figure 3, it can be seen that the number of tons loaded in vessels of the world fleet has kept increasing for the last 40 years; in fact it has trebled since the 1970s. 


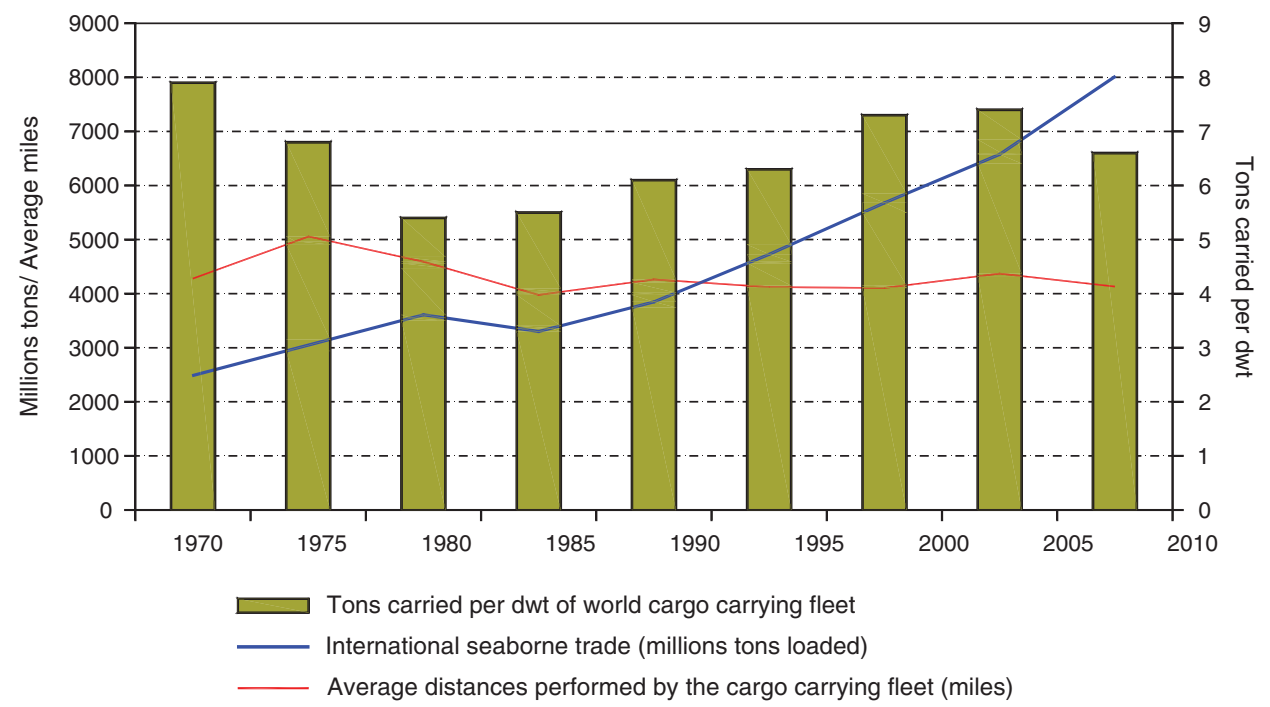

Figure 3. Evolution in selected years of the international seaborne trade, average distances performed by merchant vessels and tons carried per dwt of the world fleet.

Sources: UNCTAD-Review of Maritime Transport (various) (http://www.unctad.org) and Fearnleys Annual Review (various issues) (http://www.fearnleys.com).

However, both the number of tons carried per unit of transport capacity (dwt) and the average miles steamed by the vessels of the world fleet fluctuate within certain boundaries (between 5 to 8 tons per dwt and between 4000 and 5000 miles, respectively) (UNCTAD, 2010, p. 64). In fact, these figures are now similar to, or even lower than, those in 1970, which indicates that it is not the increase in the average speed of the vessels of the world cargo carrying fleet that has fulfilled the growing demand for sea transport, but the increase in the number of ships (UNCTAD, 2011, pp. 36-41) and in their size (Lloyd's List, 2011c). Although it would have been technically feasible to increase the speed, the growing importance of fuel costs in the operation of vessels since the 1970s has prevented it (Stopford, 2009, p. 233).

This macroeconomic process reflects that, with the aim of making their activity more profitable among their competitors (Lloyd's List, 2011h), the business strategies of ship-owners, greatly conditioned by the costs of running their vessels, have focused on ordering more efficient ships. This efficiency has been achieved mainly by means of introducing technical advances and improving economies of scale (The Motorship, 2011c). Even though there are some elements for which shippers might be prepared to pay (speed, transport reliability and security), the freight cost is known to be the factor on which they are likely to place more emphasis (Lloyd's List, 2012g). Both shippers and ship-owners behave in this way because many commodities could not be transported by sea if these costs increase (Culliname, 2010, p. 405). Actually, the influence of transport costs on a country's trade competitiveness is such an important factor that a perceptible increase in these costs can cause serious economic problems (UNCTAD, 2011, p. 64). The consequence of this pressure on the cost of transport has been that the shipping industry, exploiting technical developments, has achieved extraordinary price reductions compared to other sectors of the economy (Stopford, 2009, p. 73). 
Obtaining cheaper transport is what really interests shippers. As a consequence, managers of shipping companies tend to assume certain risk alternatives related to transport cost reductions. Therefore, low running costs per unit of cargo carried have become suitable risk alternatives to satisfy the growing demand for the past few decades (Lloyd's List, 2011a). This characteristic has not only made ship-owners reduce operating costs (by improving ship design and introducing technical advances and automation on vessels) but it has also compelled shipping companies to introduce global reductions in the exploitation costs. Certain changes in national regulations and the fact of registering vessels in 'flag of convenience' countries have made these policies possible. These practices have also helped ship-owners to establish cost reduction policies concerning manning, the most important part of the operating costs of ships (LLP, 1988). In fact, most of the shipping companies worldwide can now operate their ships in an unrestricted international labour market (BIMCO/ISF, 2010).

Nonetheless, implementation of policies concerning crew quantity and quality and the introduction of technical advances has brought about new sources of risk (Maritime Journal, 2012). Onboard, many jobs have changed from task-oriented to supervision-oriented and shift work has increased in port due to faster loading and unloading operations; both facts have made the crew members performing tasks on board more prone to human failures (AIBF, 2008). With regard to navigation tasks, the comfort of modern bridges and the reliability of technical equipment, combined with excessive working hours, have created an environment which weakens the state of alertness of people on watch (AIBF, 2008).

The effect of these changes on the level of safety of vessels is reflected in many accident investigations that repeatedly show that fatigue and related problems are a current cause of navigation incidentss (ATSB, 2011). Thus, fatigued officers and the lack of lookouts are the causes of many groundings and collisions (IMO, 2009); actually, approximately $11-25 \%$ of those collisions and groundings are, directly or indirectly, influenced by fatigue (IMO, 2005). Other investigations show that one in four seafarers has fallen asleep while on watch and that almost $50 \%$ of them work more than 85 hours a week (Smith, 2007). In fact, sleeping, or sleepiness, during the bridge watchkeeping period is a factor that contributes to many accidents (Phillips, 2000).

This situation reflects that the human element onboard has become a growing source of risk and the major cause of shipping incidents (Lloyd's List, 2008b). The expansion of this problem has been parallel to the widespread development of shipping business policies related to cost reduction in the operation of vessels, mainly affecting manning (Fairplay, 2010). This cause and effect relationship indicates that the level of safety concerning crew performance has been exchanged for a more profitable activity by ship-owners (The Motorship, 2003). All these facts reflect the risk compensation behaviour adopted by the managers of shipping companies.

The desire to reduce costs related to quantity and quality of manning has led shipping companies to exert control of many issues concerning ship activity and safety from ashore (such as planned maintenance, machinery diagnosis, cargo plans and crewing policies) (Lloyd's List, 2012c). The reliability of technical advances, automation and radio communications has made this possible (The Motorship, 2010). As a result, managerial tasks have become more relevant in the commercial activity of vessels than the skills of the people on board (The Motorship, 2008). 
In such a context, the overriding responsibility of ships' Masters to make decisions with respect to safety, based on traditional manning principles and established in regulations (IMO, 2002) becomes, to a certain extent, a fictitious but convincing argument to protect the shipping business' interests. Actually, the growing concern for the treatment of seafarers in the event of maritime accidents highlights that these principles are perceived as old-fashioned (IMO, 2006).

\section{THE RISK HOMEOSTASIS PROCESS CONCERNING HUMAN} ELEMENT ON BOARD. As stated in Section 3, the level of risk accepted in the operation of ships is strongly influenced by the shipping market - the place where shipping companies deal with the commercial affairs of their vessels. This fact makes ship-owners into key players in the risk taking process and leads them to interfere with the safety of their vessels. Actually, specialized media repeatedly reflect that ship-owners often risk safety in one or more ways: either by withdrawing assistance to navigation (Lloyd's List, 2011d), or by cutting costs (Lloyd's List, 2012a), or by undercutting vital maintenance (Lloyd's List, 2012e) especially in periods of economic downturn (Lloyd's List, 2010), or even by providing crews with incentives whenever they want them to face particular risk ventures (Lloyd's List, 2008a).

In addition to interfering directly with the vessels' safety affairs, there is also evidence that, by altering the likelihood of occurrence of mishaps through the establishment of restrictive manning policies on board, managers of shipping companies introduce risks on board (Smith, 2007). Risks that perceptibly affect the safety of vessels since the capacity of those in charge of navigation tasks, such as watchkeepers and lookouts, to execute safe navigation is highly sensitive to working conditions which significantly alter their psychophysical rhythms (Plett et al., 1988). The extension of these practices, and their effects upon vessels' safety, are reflected in the fact that fatigue is an omnipresent risk in the operation of commercial ships nowadays (Lloyd's List, 2012i). The results of the investigations into many accidents confirm this theory since they state that it is the lack of alertness of people on board which is the usual cause of incidents (The Motorship, 2012b). This reality highlights how managerial policies concerning both quantity and quality of manning and working conditions on board reduces the ability of the crews to achieve a safe performance (Lloyd's List, 2009).

In this context, the risk homeostasis theory posits that in the exploitation of their vessels ship-owners will attempt to assume the level of risk which allows them to maximize the net benefit of the activity, which is called the Target Level of Risk. For this purpose, when deciding the way to man their vessels, the managers of shipping companies compare the amount of risk they perceive to the target level of risk, adjusting their behaviour to eliminate any difference between the two. Every ship activity involves a particular level of accident likelihood, and the sum of those activities explains the rate of shipping accidents in the long run. This rate, in turn, influences the level of risk ship-owners perceive in an activity. This mechanism causes a closed loop process in which the degree of caution in the operation of vessels determines the rate of accidents. A change in this rate also leads to a change in the behaviour of the management of the shipping companies (Wilde, 1994).

This homeostatic mechanism is so complex that it is difficult to explain how it works, especially if we take into consideration that there are many people engaged in 
the operation of vessels and that managers of shipping companies have no direct control over the daily behaviour of the people on board. Crews are not passive elements in this risk process; actually, they display their own behaviour when facing risks. In fact, there is evidence that by exchanging the safety standard of vessels for riskier operations, crews participate in the risk compensation activity of their companies (Baniela and Rios, 2010). Nevertheless, ship-owners and crews perceive the advantages and disadvantages of safe and unsafe behaviour alternatives in different ways. For crews, this perception determines the degree to which they are willing to expose themselves to hazards, whereas, for management, it determines the level to which they will expose their companies to economic losses. Despite these differences, shipping business dynamics necessarily demand that all people involved in the activity follow the ship-owners' aim so as to maximize the benefits obtained from the operation of their ships. This requires shipping companies to adjust their manning policies to balance the target level of risk. Such an objective must, necessarily, be achieved by subordinating the crews' cultural, social and psychological factors that influence their risk tolerance to the ship-owners' interests (Lam, 2003, p. 21).

This approach leads us to accept that it is the risk compensation behaviour of the shipping business decision-makers that causes the fluctuation of the rate of shipping accidents around the level shown in Figure 1. In this process of trying to force the operation of vessels to maintain a subjectively ideal level of tolerated risk, the people on board are only in charge of managing the amount and type of risks that others have arranged for them to assume. The way in which shipping accidents caused by the human errors of those on board affect human life or the environment and the importance of the economic losses that these incidents cause to shipping companies, both alter the level of perceived risk of those managing the shipping business (The Motorship, 2005).

Evidence for the above mentioned risk homeostasis process is shown in the statistics related to the typical navigation accidents: collisions and groundings. Despite the important technical improvements in the safety of navigation introduced in vessels during the last 60 years, the rate of errors in navigation tasks has not decreased (Lloyd's List, 2012b). In fact, before the IMO started its work in 1959, at a time when there was almost no electronic equipment on the bridges of ships, the ratio of collisions and groundings to total shipping casualties was around 2:5 (Mapplebeck, 2006). If we compare that to today's ratio, it can be seen that, despite the massive introduction of accurate electronic navigation instruments and shore assistance, the ratio of errors causing collisions and groundings remains similar (The Motorship, 2011a). This indicates that the increase in safety due to navigation advances during this period has been exchanged for profits associated to reductions in costs, mainly in manning (The Motorship, 2005). As a result, the occurrence of shipping accidents fluctuates, keeping pace with the shipping market circumstances, as shown in Figure 1 and, among these mishaps, those that better represent human errors in the conduct of navigation, collisions and groundings, maintain an unaltered ratio over the years, as shown in Figure 4.

Even considering that waters are more congested now than they were in the 1950s, accident investigations have shown that collisions, for instance, can happen to any ship, irrespective of age, type and location. Actually, insurance industry investigations reflect that one in five collisions occurs on the open sea and that most of them take place in good visibility and calm seas and even with ships at anchor 


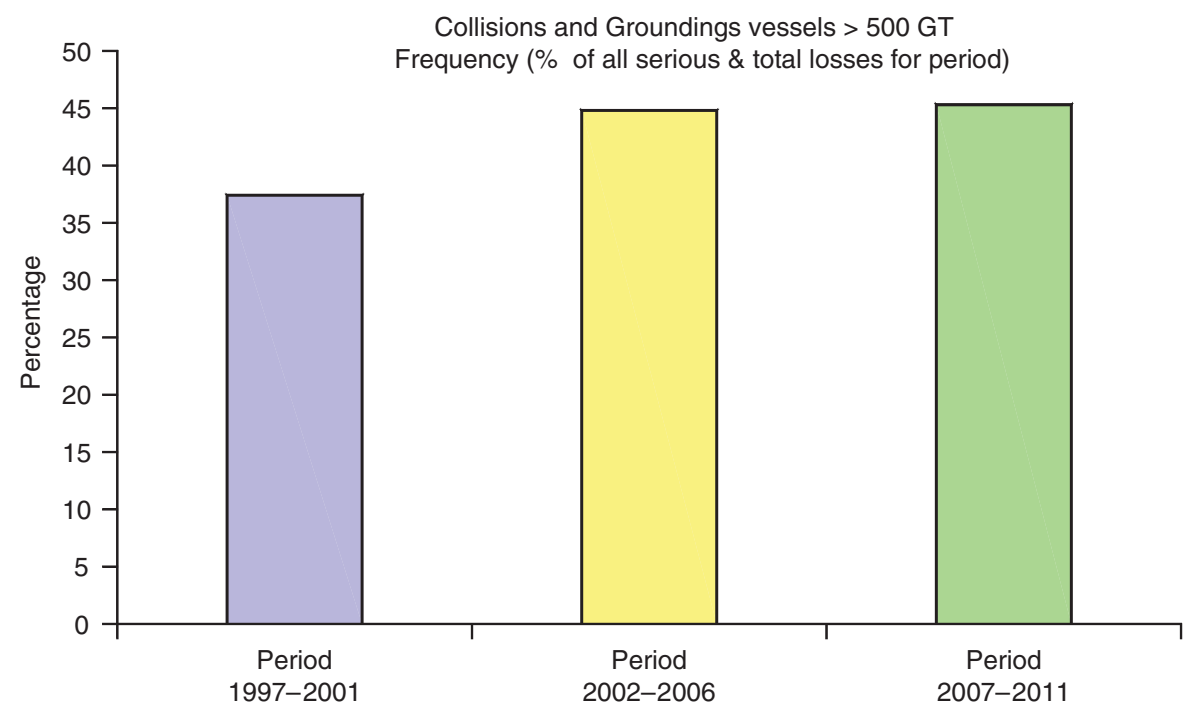

Figure 4. Collisions and groundings of vessels over 500 grt in selected periods as percentages of all serious and total losses. Source: IUMI (http://www.iumi.com/).

(UK P\&I Club, 1994). This leads to the consideration that the proneness of those engaged in watchkeeping activities on vessels to make fatal mistakes does not depend on the difficulties of navigation. Many investigations support this conclusion by pointing to working conditions as a source of risk on board (Phillips, 2000).

The statistics shown in Figure 4 lead us to consider that accident countermeasures, including the establishment of safety management systems on board (IMO, 2002), do not achieve perceptible results. This hints at the ineffectiveness of accident prevention regulations, introduced as a result of the investigations carried out by maritime administrations. The main reason for this failure is that such investigations, which repeatedly blame the mishaps on the crew, justify both the introduction of new technical advances on ships and the investment in training to familiarise seafarers with these safety advances, without ever questioning the suitability of manning established by shipping companies and supported by the minimum safe manning document issued by the administrations.

Unquestionably, safety advances, mainly focused on improving navigation equipment and the technical skills of the people on board, increase the crews' ability to operate vessels safely, but they do not necessarily increase the ship-owners' willingness to implement the safe operation of their ships, due to the great influence that the shipping market conditions exert on them, as has been stated above. Consequently, according to the risk homeostasis theory, the safer a commercial ship is, the easier she will make it for her shipping company to face more profitable risks.

5. CONCLUSIONS. Empirical investigation shows that rise and fall in the level of ship-owners' profits, caused by the alterations of the shipping market, 
influence the amount of risk tolerated in the operation of ships. It should also be taken into consideration that ship-owners are conditioned to assume certain types of risk alternatives focused on reducing the running costs of ships by the market.

Among these, the reduction in manning costs to make the vessels more efficient among the competition has become a current policy in shipping business. Both the fitting out of ships with more technical safety improvements and the existence of an unrestricted internationalized labour market have made these practices possible. The repetition of human errors in shipping casualties emerges from this process of adapting to the shipping market demand. This is a process in which shipping business decision-makers tend to use safety improvements and the level of technical performance of the people on board to adopt more profitable and riskier alternative activities.

Despite the introduction of important advances in the safety of navigation during the last decades, risk compensation behaviour has caused the rate of marine navigation accidents to remain unaltered over the years, as statistics of the insurance industry show. This fact indicates that a risk homeostasis process is taking place in commercial shipping activity. Human errors, as the main cause of shipping accidents, should not be considered solely a consequence of voluntarily accepted sources of risk by the personnel on board, but mainly as a result of practices and manning policies imposed by managers of shipping companies on account of the pressure of the shipping market to reduce transport costs.

Accident investigations performed by maritime administrations usually put the blame for incidents on seafarers, without taking into account that ship-owners impose risks related to the psychophysical capabilities of the people on board. Accident countermeasures are mainly directed towards introducing new technical advances and improving the skills of the crews and their adaptation to these safety reforms, without ever considering the suitability of the quantity and quality of crew members and the working conditions established on board. According to the risk homeostasis theory, these advances can be transformed into a more efficient risk activity by ship-owners, because the more accurate the technical equipment and the more qualified the crews, the better able they will be to face risks. The resulting rate of accidents will alter the risk perceived by the managers of shipping companies in proportion to the damages caused to the business by the mishaps, a closed-loop process which maintains the rate of accidents fluctuating around a level acceptable to the industry.

\section{REFERENCES}

AIBF (2008). Accident Investigation Board Finland. Factors contributing to fatigue and its frequency in bridge work. (Investigation report S3/2004M), Helsinki.

ATSB (2011). Australian Transport Safety Bureau. Watch-keeper fatigue a significant safety risk on ships. Media Release, 14 April 2011, (http://www.atsb.gov.au/newsroom/2011).

Baniela, S. I. and Ríos, J. V. (2010). The Risk Homeostasis Theory. The Journal of Navigation, 63, 607-626. BIMCO/ISF (2010). Manpower 2010 update. The worldwide demand for, and supply of, seafarers. Highlights. Warwick Institute for Employment Research.

Boisson, Philippe. (1999). Safety at Sea: Policies, Regulations \& International Law. Paris, Edition Bureau Veritas.

Culliname, K. (2010). International Handbook of Maritime Economics. Massachusetts, Edward Elgar Publishing, Inc.

Fairplay (2010). Counting the cost of fair treatment, 15 July 2010, (http://www.fairplay.co.uk). 
Heitzmann, W. Ray (2006). Opportunities in Marine Science and Maritime Careers. New York, McGraw-Hill.

IMO (2002). International Safety Management Code, Part A-5.2.

IMO (2005). STW 37/INF.5. Education and training requirements for fatigue prevention, mitigation and management, 18 November 2005.

IMO (2006). Resolution A.987(24). Guidelines on fair treatment of seafarers in the event of a maritime accident.

IMO (2009). STW 41/8/1. Review of the principles for establishing the safe manning levels of ships, 5 November 2009.

Lam, James (2003). Enterprise Risk Management: From Incentives to Controls. New Jersey, John Wiley \& Sons, Inc.

Lloyd's List (2008a). Captains' rewards are outweighed by the risks, 23 June.

Lloyd's List (2008b). Crew quality hits marine claims, 14 April.

Lloyd's List (2009). MAIB issues fresh advice in wake of grounding, 22 April.

Lloyd's List (2010). Ship operating costs fall, 29 September.

Lloyd's List (2011a). Box lines warned to order large ships or be squeezed out of market, 23 June.

Lloyd's List (2011b). German owners edge closer to use of on-board armed guards, 3 August.

Lloyd's List (2011c). Mega box-ships need port design to jump into 'next league', 2 December.

Lloyd's List (2011d). Owners risk safety by cutting costs on pilotage, 02 August.

Lloyd's List (2011e). Owners seek danger money as pirates move north, 03 February.

Lloyd's List (2011f). Slow steaming is here to stay for VLCCs, 30 November.

Lloyd's List (2011g). Spread of piracy prompts west coast India rate premium, 06 January.

Lloyd's List (2011h). Ultra-large box-ships push smaller carriers onto secondary trade routes, 06 July.

Lloyd's List (2012a). Exclusive: Cost-cutting ship-owners compromise tanker safety, 16 March.

Lloyd's List (2012b). Human factor plays key safety role, 12 April.

Lloyd's List (2012c). More hands on deck, 08 June.

Lloyd's List (2012d). One master in four has faced criminal charges, 20 April.

Lloyd's List (2012e). Owners taking risks with cargo hatchcovers, 16 February.

Lloyd's List (2012f). Panamax owners idling ships as charter rates keep falling, 10 January.

Lloyd's List (2012g). Shippers praise carriers for adapting to true competition, 21 February.

Lloyd's List (2012h). Troubled tanker owners put quality and safety at risk, 22 March.

Lloyd's List (2012i). Up to $45 \%$ of watchkeepers fall asleep on the job, 31 January.

LLP (1988). Which register? Which flag...now? (Proceedings of Conference). New York, 19-20 October 1988. Lloyd's of London Press, Inc., New York.

Mapplebeck, G. (2006). Navigational safety and the challenges of electronic navigation. Middlesbrough, (http://www.imo.org/KnowledgeCentre).

Maritime Journal (2012). A hundred years of changes, but challenges remain, 17 April 2012, Mercator Media Ltd, Hampshire, (UK), (http://www.maritimejournal.com).

Phillips, Richard (2000). Sleep, watchkeeping and accidents: a content analysis of incident at sea reports. Transportation Research Part F, 3, 229-240.

Plett, R., Colquhoun, W. P., Condon, R., Knauth, P., Rutenfranz, J. and Eickhoff, S. (1988). Work at sea: a study of sleep, and of circadian rhythms in physiological and psychological functions, in watchkeepers on merchant vessels. III. Rhythms in physiological functions. International Archives of Occupational and Environmental Health, 60, 395-403.

Smith, A. (2007). Adequate Crewing and Seafarers' Fatigue: The International Perspective. Cardiff University, (http://www.itfseafarers.org).

Stopford, Martin (2009). Maritime Economics, $3^{\text {rd }}$ ed. New York, Routledge.

Talley, Wayne K. (2012). The Blackwell Companion to Maritime Economics. West Sussex, Blackwell Publishing Ltd.

The Motorship (2003). New standards to ensure safer and more efficient operations by ships' crews, 29 October. Mercator Media Ltd, Hampshire, (UK), (http://www.motorship.com).

The Motorship (2005). P\&I club calls for greater investment in ships' crews, 16 September. Mercator Media Ltd, Hampshire, (UK), (http://www.motorship.com).

The Motorship (2007). Increasing incidence of serious accidents, 20 March. Mercator Media Ltd, Hampshire, (UK), (http://www.motorship.com).

The Motorship (2008). Invitation to break with maritime traditions, 08 August. Mercator Media Ltd, Hampshire, (UK), (http://www.motorship.com). 
The Motorship (2010). Communications choice, 19 October. Mercator Media Ltd, Hampshire, (UK), (http://www.motorship.com).

The Motorship (2011a). Caution remains in hull and machinery insurance, 29 October. Mercator Media Ltd, Hampshire, (UK), (http://www.motorship.com).

The Motorship (2011b). Safety statistics reversed, says DNV, 23 May. Mercator Media Ltd, Hampshire, (UK), (http://www.motorship.com).

The Motorship (2011c). The bulk carrier of the future, 30 November. Mercator Media Ltd, Hampshire, (UK), (http://www.motorship.com).

The Motorship (2012a). A fall in rates causes concern, 15 May. Mercator Media Ltd, Hampshire (UK) (http://www.motorship.com).

The Motorship (2012b). Addressing the human fatigue question, 28 February. Mercator Media Ltd, Hampshire, (UK), (http://www.motorship.com).

UK P\&I CLUB (1994). The Anatomy of Major Claims. A Mariners' Guide, (http://www.ukpandi.com/lossprevention/article/anatomy-of-major-claims-861/).

UNCTAD (1999). United Nations Conference on Trade and Development. Review of Maritime Transport 1999, (http://www.unctad.org).

UNCTAD (2008). United Nations Conference on Trade and Development. Review of Maritime Transport 2008, (http://www.unctad.org).

UNCTAD (2010). United Nations Conference on Trade and Development. Review of Maritime Transport 2010, (http://www.unctad.org).

UNCTAD (2011). United Nations Conference on Trade and Development. Review of Maritime Transport 2011, (http://www.unctad.org).

Wilde, G. J. S. (1998). Risk homeostasis theory: an overview. Injury Prevention 4, 89-91.

Wilde, G. J. S. and Simonet, S. L. (1996). Economic fluctuations and the traffic accident rate in Switzerland: a longitudinal perspective. Swiss Council for Accident Prevention, Berne.

Wilde, G. J. S. (1994). Target Risk. Toronto, PDE Publications. 